DOI: $10.14746 /$ por.2019.1.16

\title{
UWIĘZIENI W KOLE SAMSARY. TWÓRCZOŚĆ SAMUELA BECKETTA W ŚWIETLE WYBRANYCH POJĘĆ FILOZOFII DALEKIEGO WSCHODU
}

\author{
AnNa GryszKiewicz ${ }^{1}$ \\ (Uniwersytet Gdański)
}

\begin{abstract}
Słowa klucze: Beckett, buddyzm, Daleki Wschód, zen, Suzuki, samsara Keywords: Beckett, Buddhism, Far East, Zen, Suzuki, samsara
\end{abstract}

\begin{abstract}
Abstrakt: Anna Gryszkiewicz, UWIĘZIENI W KOLE SAMSARY. TWÓRCZOŚĆ SAMUELA BECKETTA W ŚWIETLE WYBRANYCH POJĘĆ FILOZOFII DALEKIEGO WSCHODU. „PORÓWNANIA" 1 (24), 2019. T. XXIV, S. 195-212. ISSN 1733-165X. W badaniach autorka zestawia twórczość Samuela Becketta z wybranymi koncepcjami filozoficznymi Dalekiego Wschodu. Artykuł nawiązuje do pierwszej tego rodzaju interpretacji w polskich badaniach beckettologicznych, którą zaproponował Piotr Dariusz Klimczak w pracy „Trylogia Tanatyczna Teatru Absurdu”. Autorka stawia tezę, że proza i dramaty Becketta, jako te, które wyrosły na tle dyskursów egzystencjonalnych, są w stanie w niebezpośredni sposób „przewodzić” idee buddyzmu i hinduizmu. Jednak, inaczej niż w pracach innych badaczy takich jak Lidan Lin i Pavneet Kaur, nie opiera związku Becketta ze Wschodem tylko na postaci Artura Schopenhauera. Za istotną podstawę swoich badań uznaje natomiast triadę Beckett - Heidegger - Suzuki, według schematu której pewne koncepcje filozofii Wschodu, a przede wszystkim nauki szkoły Zen, mogłyby dotrzeć do Becketta jako echo wpływu filozofii Martina Heideggera.
\end{abstract}

Abstract: Anna Gryszkiewicz, TRAPPED IN THE WHEEL OF SAMSARA. THE WORKS OF SAMUEL BECKETT IN THE LIGHT OF CHOSEN ELEMENTS OF THE FAR EAST PHILOSOPHY. "PORÓWNANIA" 1 (24), 2019. Vol. XXIV, P. 195-212. ISSN 1733-165X. The author confronts Samuel Beckett's works with selected concepts of Eastern philosophy. The article expands previous research conducted by Piotr Dariusz Klimczak, contained in his thesis "Theatre of the Absurd. Thanathic Trilogy" and is based on the hypothesis that Beckett's dramas and novels, as ones which arise on the existential philosophical discourse background, can in an indirect way

1 E-mail: anna.gryszkiewicz@ug.edu.pl 
transmit the basic doctrines of Buddhism and Hinduism, though not without some shifts to the original philosophical system. The author, unlike in Lidan Lin and Pavneet Kaur studies which consider Artur Schopenhauer as the main East West connecting link, locates the basis of his research in a three-person scheme, Beckett - Heidegger - Suzuki, according to which Eastern philosophy, especially the teachings of the Zen school, could reach Beckett as an echo of the influence of Heidegger's ontology.

Już po przeczytaniu tytułu niniejszego artykułu część polskich beckettologów może poczuć, że w badania nad europejskim twórcą wkradł się niepotrzebny wątek. Z początku czytelnik oczekiwać będzie, że zostanie mu wyłożony dowód na dalekowschodnie podróże pisarza lub dotąd nieznane inklinacje z kulturą Wschodu, które to inklinacje zaowocowały dającą się precyzyjnie wyeksplikować symboliką literacką. Stwierdzenie o kluczowym dla uzyskania statusu „naukowości” trzymaniu się faktów podczas prób rozczytywania tekstów autorów zachodnich poprzez konteksty odległe nie jest żadnym zarzutem (jest wręcz uproszczeniem) i zasadza się na poczuciu, że terminologia związana z systemami myśli dalekowschodniej budzi niekiedy newage'owe, ezoteryczne skojarzenia. Stąd sięgające tradycji Wschodu badania komparatystyczne na gruncie polskim wciąż mają niestabilną, niszową pozycję. Opór w polskiej humanistyce przed podejmowaniem rzeczywistej próby przekroczenia tej jakże umownej granicy Wschód - Zachód jest na szczęście coraz rzadszy i tłumaczy się, jak zgaduję, rzetelnością polskich badaczy, którzy - być może pod presją silnych trendów postkolonialnych - bronią się przed wchodzeniem na nieznany teren, gdzie przecież tak łatwo o uchybienia i nieopatrzną "orientalizację" (za Edwardem Saidem).

Rozpoczęcie badań mających na celu poszerzenie zasobu dostępnych narzędzi percypowania twórczości Samuela Becketta o pojęcia filozofii buddyjskiej może więc jawić się jako propozycja marginalna chociażby z dwóch powodów. Po pierwsze, Becketta od lat bada się w świetle pojęć kultury chrześcijańskiej, powstaje więc pytanie, po co zmieniać kurs dociekań, które przynoszą wciąż nowe owoce, a jednocześnie są wykonywane w bezpiecznym, znanym obszarze znaczeń kulturowych. Po drugie, dlaczego sięgać do pojęć buddyzmu, którego ontologiczne i kosmologiczne założenia są dalece odmienne od "naszych”, a niekiedy nawet zaprzeczają tym wypracowanym w paradygmacie kultur zachodnich. Odpowiedź kryje się właśnie w owych różnicach między myślą filozoficzną Wschodu i Zachodu, których dogłębne rozpoznanie, jak mniemam, pozwoli spojrzeć na świat bohaterów, takich jak Clov, Molloy czy Winnie, jako na świat, w którym dewaluacja chrześcijańskich wartości nie równa się aksjologicznej pustce. Zaproponowane przeze mnie czytanie Becketta pozwala również z odmiennej perspektywy przyjrzeć się warstwie językowej dzieł pisarza. Narracje, dialogi i monologi, utkane z nielogicznych składniowo wypowiedzi i układające się w afabularny, hybrydyczny porządek, wtłoczone, na potrzeby badań, w dalekowschodni kanon myśli o świecie i jego właściwościach, przywodzą nowe konstelacje znaczeń. Potrzeba prowadzenia zaproponowanych 
badań wynika również z założenia, że owo Saidowskie odbijanie się Zachodu w lustrze Wschodu może, choć nie bez przekłamań, pomóc nam zrozumieć właściwy sens dzieł Becketta.

Przyglądanie się twórczości Samuela Becketta poprzez pryzmat filozofii buddyjskiej to mimo wszystko temat nie do końca obcy polskim beckettologom. Niektórzy z nich mogą poszczycić się interesującymi, acz, jak pisałam, wciąż zajmującymi w rodzimym dyskursie akademickim raczej marginalną pozycję, osiągnięciami w badaniach komparatystycznych nad Beckettem w świetle nurtów filozoficznych Dalekiego Wschodu. W niniejszym eseju chciałabym przybliżyć kilka istniejących propozycji odczytania Becketta w perspektywie myśli buddyjskiej oraz rozwinąć wybrane wątki tejże refleksji.

Polscy badacze, w tym znakomity Antoni Libera, wielokrotnie wskazywali tropy interpretacyjne, które sięgają daleko poza krąg motywów teologicznych wywiedzionych z wierzeń i mitologii społeczności zachodnioeuropejskiej ${ }^{2}$, ale w niemalże wszystkich przypadkach skojarzenia te są bardzo ogólne, czasem nawet tendencyjne, i opierają się raczej na przeczuciu pewnych potencjalnych zbieżności. To niekiedy pobieżne podejście nie dziwi, jeśli się weźmie pod uwagę wiele czynników, chociażby trudności związane z odmienną kosmogonią, symboliką czy pamięcią historyczną, czyli niewystarczające zaplecze badawcze, które socjolog Florian Znaniecki nazwałby obniżonym współczynnikiem humanistycznym zjawisk i wierzeń osadzonych w kulturach azjatyckich (Znaniecki 470). Co więcej, polskie interdyscyplinarne środowisko naukowe, w którym mógłby na dobre rozwinąć się dyskurs kulturoznawczy i literaturoznawczy o charakterze euroazjatyckim, jest wciąż, pod względem liczby zaangażowanych badaczy, skromne. Szkoda tym bardziej, że prace niektórych polskich teatrologów-orientalistów świadczą o wielkim potencjale w tym obszarze ${ }^{3}$. Gdy mowa o percepcji dramaturgii Becketta, w której relatywizm kulturowy ustępuje antropologicznej ciekawości odkrywania twórczości pisarza przez pryzmat nurtów filozoficznych Dalekiego Wschodu, spośród osiągnięć polskich badaczy należy wyróżnić prace Dariusza Piotra Klimczaka. W pierwszym tomie Trylogii Tanatycznej Teatru Absurdu, zatytułowanym Śmiertelnicy. Teatr Absurdu Samuela Becketta w przestrzeni Misterium Mortis, podejmuje się on analizy trzech sztuk Becketta ${ }^{4}$, stawiając je w świetle wybranych pojęć teologicznych, w tym pojęć

2 Wiele z tych tropów przedstawia spisany dialog Antoniego Libery z dominikaninem Januszem Pydą OP Jesteście na Ziemi, na to rady nie ma! Dialogi o teatrze Samuela Becketta wydane przez Dominikańskie Studium Filozofii i Teologii w 2015 roku.

3 Nawiązuję tu przede wszystkim do Zbigniewa Osińskiego i jego monumentalnego dwutomowego dzieła Polskie kontakty teatralne z Orientem w XX wieku wydanym przez Wydawnictwo słowo/ obraz terytoria w Gdańsku 2009 roku, w którym autor systematyzuje według chronologii zdarzeń najważniejsze wizyty teatrów Azji i Oceanii w Polsce, podsuwając jednocześnie czytelnikowi różne świadectwa recepcji przez polskich artystów.

4 Klimczak w drugim, trzecim i czwartym rozdziale książki Śmiertelnicy. Teatr Absurdu Samuela Becketta w przestrzeni Misterium Mortis analizuje kolejno Końcówkę, Czekając na Godota oraz Szczęśliwe Dni. 
z zakresu filozofii wedyjskiej i buddyjskiej. W zmienionej i rozbudowanej wersji rozprawy doktorskiej ${ }^{5}$, którą Klimczak obronił na Uniwersytecie Jagiellońskim pod kierunkiem Małgorzaty Sugiery, możemy przyglądać się Beckettowi poprzez figurę śmierci i jej celebrację. Klimczak koncentruje się na związanych ze śmiercią i obrządkami funeralnymi obrazach i totemach, które w innych kulturach przywołują konkretne znaczenie, ale jednocześnie, dzięki swym archetypicznym właściwościom, są w stanie uruchomić w każdym odbiorcy, niezależnie od pochodzenia i identyfikacji społecznej, równie silne emocje. Użycie tematologii literackiej jako narzędzia metodologicznego powoduje, że makata uszyta z niejednorodnych historycznie i kulturowo motywów, które badacz łączy z wątkami Beckettowskimi, jest niezwykle barwna. W kontekście zaproponowanych przeze mnie hipotez na szczególną uwagę zasługują rozdziały: Przestrzeń tanatyczna. Symbolika kopca-kurhanu-buddyjskiej stupy oraz Przestrzeń solarna - głowa - dzwonki. W stronę Bar-do thos-grol, w których autor posługuje się wybranymi pojęciami z zakresu filozofii i kosmogonii Dalekiego Wschodu, by wyjaśnić symbolikę przestrzeni dramatycznej utworów Becketta. Zarówno wspomniane rozdziały książki Śmiertelnicy... (której jądrem staje się tytułowe Misterium Mortis, widziane okiem pozbawionego przynależności kulturowej autora-erudyty), jak i wydany dwa lata wcześniej artykuł Klimczaka, Medytacja nad Pustką. Konteksty buddyjskie w Końcówce i Szczęśliwych dniach Samuela Becketta, skłoniły mnie, by odważyć się na interpretację polegającą na umiejscowieniu dramaturgii Samuela Becketta w paradygmacie kultury buddyjskiej.

\section{Beckett. Schopenhauer...}

Poza polskim, raczej marginalnym wkładem w badania nad buddyjskim kontekstem twórczości Becketta, o którym piszę we wstępie, należałoby wymienić kilka prac autorów zagranicznych, którzy zdążyli już rozwinąć ów wątek wschodni u Becketta w niekiedy bardzo obszerne prace naukowe. Większość z nich łączy przekonanie, że najważniejszym nośnikiem wiedzy o Wschodzie był dla Becketta Artur Schopenhauer. W tym aspekcie moje badania różnią się zasadniczo od wymienionych, do czego wracam $\mathrm{w}$ kolejnym rozdziale.

Pierwsze próby interpretowania Becketta przez filozofie wschodnie pojawiły się w 1964 roku za sprawą książki Richarda N. Coego pt. Beckett. Natomiast dalece bardziej wyczerpującą analizę komparatystyczną z wykorzystaniem wiedzy na temat buddyzmu i hinduizmu zaproponował w 1976 roku Steven J. Rosen w publikacji Samuel Beckett and the pessimistic tradition. Wydaje się, że duża część artykułu autor-

5 W 2005 roku Klimczak został wyróżniony w Ogólnopolskim Konkursie na najlepszą rozprawę doktorską z dziedziny nauk o kulturze organizowanym co roku przez Narodowe Centrum Kultury Instytut im. Adama Mickiewicza w Warszawie. 
stwa Lindan Lin Samuel Beckett's Encounter with the East z 2010 roku, nad którą chciałabym się na moment pochylić, jest właśnie pochodną lektury Rosena. Praca Lin na arenie badań nad twórczością Becketta w świetle wpływów dalekowschodnich jest ważna ze względu na jej metodologiczne rozwarstwienie. Lin próbuje przyjrzeć się Beckettowi z dwóch różnych perspektyw, wschodniej filozofii oraz estetyki, przy czym nie różnicuje obu tych obszarów. Tekst Lin staje się tym samym unaocznieniem trudnego wyboru, przed jakim staje każdy badacz próbujący ukonstytuować swoją pozycję w tym jakże wymykającym się wszelkiej kategoryzacji obszarze badawczym. Lin z jednej strony stara się wykazać pojęciową zbieżność między Schopenhauerowskim rozumieniem świata oraz stanowiskiem ontologicznym Becketta z esejów Proust i Henri Hayden - człowiek-malarz, z drugiej próbuje udowodnić, że wiedza Becketta o Wschodzie nie pochodziła li tylko od Schopenhauera, czyli nie dotyczyła jedynie Indii, ale opierała się także na lekturach dotyczących historii i kultury Chin, takich jak La Musique Chinoise Louisa Laloya czy The Civilization of China H.A. Giles'a (Lin 632). Lin próbuje dowieść słabości Becketta do chińskich znaków, muzyki i malarstwa klasycznego, wyszukując jednocześnie artystyczne dowody na ową estetyczną fascynację. Tekst Lin, usytuowany w szerokim kontekście bohemy Paryża lat trzydziestych, próbuje mieć jednocześnie wartość faktograficzną, archiwistyczną oraz filozoficzną, przez co niekiedy traci na spójności, ale otwiera kolejne drzwi w dyskusji o relacji Beckett - Wschód.

Pavneet Kaur w Samuel Beckett's 'The Way' and Stirrings Still: Analysing the Self from 'Schopenhauerian Buddhist' Perspective z 2017 roku bierze pod lupę prozę Becketta z lat osiemdziesiątych i przygląda się artystycznej reprezentacji myśli filozoficznej Becketta z punktu widzenia „pozytywnej pustki”, którą w tekście nazywa (zapożyczonym z Richard Wagner and Buddhism Ursa Appa) „Schopenhauerowskim buddyzmem" (Kaur 70). Bytność owej ideologicznej hybrydy obrośniętej symboliką Wschodu i Zachodu, której Kaur jest spadkobierczynią (między innymi po Rosenie i Lin), zasadza się na wynegocjowaniu wspólnego obszaru pojęciowego dla zależności między jaźnią a światem zewnętrznym, gdzie nieustannie toczy się gra na linii ja - świat. Jak tłumaczy Kaur, podobnie jak gra nie ma końca, również jaźń jest procesem, który nie ma końca. Wspomniana transfilozoficzna hybryda Kaur opiera się w dużej mierze na pojęciu "pustości”, ale w jego buddyjskim, pozytywnym, uwalniającym rozumieniu. Najciekawszy bodaj fragment artykułu Kaur odnosi się do „medytacyjnego" charakteru późnej twórczości prozatorskiej pisarza. Oryginalne techniki literackie Becketta są według niej udaną próbą sportretowania uniwersalnej natury jaźni.

W zbiorach bibliotecznych Departamentu Literatury Zagranicznej National Cheng Kung University znajdują się dwie prace magisterskie autorstwa Meng-Ling Chien i Shih-ping Hsiao, których tematem jest twórczość Samuela Becketta widziana z perspektywy filozofii Wschodu, obie jednak mają bardzo ogólny charakter i zasadzają się na tłumaczeniu różnic $\mathrm{w}$ definiowaniu ludzkiego cierpienia przez 
egzystencjalistów oraz mistrzów filozofii Wschodu, przy czym praca autorstwa Shih-ping Hsiao Samuel's Beckett's Waiting for Godot: Suffering and Emptiness--An Interpretation in the Light of Buddhism z 1998 roku broni się zdecydowanie bardziej klarownym podejściem metodologicznym.

W moich badaniach ważną lekturą była również rozprawa Paula Fostera Beckett and Zen: A Study of Dilemma in the Novels of Samuel Beckett, której treści nie sposób skomentować w kilku zdaniach. Stanowi ona niejako kanon w badaniach nad Beckettem z perspektywy orientalistycznej, stąd będę się do niej odnosić w trakcie całego wywodu.

\section{Beckett. Heidegger... Suzuki}

Jak już wspomniałam, większość badaczy sugeruje uznanie Schopenhaura i jego filozofii jako głównego ogniwa pośredniczącego w relacji Beckett - Wschód. W moich badaniach stawiam hipotezę, że dla Becketta owym łącznikami ze Wschodem były, poza Schopenhauerem, filozofia Martina Heideggera, a także ogólnodostępna wiedza czasów aktywności pisarskiej noblisty. Chcę jednak zaznaczyć, że hipoteza ta ma charakter pomocniczy i nie stanowi istoty badań, których celem jest raczej odwrócenie owej zależności Zachód - Wschód i wypracowanie nowej sieci pojecć, pozwalającej odmiennie niż dotychczas interpretować ważną część europejskiego, więc własnego, dziedzictwa literackiego. Kontynuując tę myśl, uważam, że twórczość Becketta jako ta, która rozwijała się na tle rozkwitu nowej myśli ontologicznej Heideggera, w sposób pośredni sama może przywoływać podstawowe doktryny buddyzmu i hinduizmu, choć nie bez pewnych przesunięć względem tychże filozofii, opartych przecież przede wszystkim na doświadczeniu empirycznym i praktycznej realizacji treści filozoficznych poprzez sukcesję na linii mistrz - uczeń (Kalinowski, źródło elektroniczne). Ujarzmienie wschodniego paradygmatu kulturowego w obrębie badań nad Beckettem, choć dzisiaj - ze względu na poszerzony dostęp do wiedzy, obecność Internetu czy aktywne migracje międzykontyntalne może wydawać się zadaniem łatwiejszym, to jednak z perspektywy badań kulturowych nad Europą lat sześćdziesiątych założenie, że inteligencja zachodnioeuropejska była pod wpływem dalekowschodnich trendów kulturowych, nie powinno budzić żadnych zastrzeżeń. Lata, kiedy Beckett tworzy Czekajac na Godota (1952), Końcówkę (1957), Ostatnią taśmę (1958) i Szczęśliwe dni (1961), to bowiem czas, kiedy zachodnioeuropejskie oraz amerykańskie środowisko naukowe i artystyczne jest już dobrze zapoznane z kulturą i filozofią Dalekiego Wschodu. Dość przypomnieć publikacje Alana Wattsa, którego tłumaczenia oraz prace autorskie przybliżyły Zachodowi nauki szkoły buddyjskiej Zen, oraz zorientowane na popularyzację buddyzmu w Europie i USA publiczne wykłady i wystąpienia telewizyjne mistrza buddyjskiego D.T. Suzukiego (Kosior 169). Od połowy XX wieku trwać będzie proces 
nieustannego nasilania się popularyzacji religii wschodnich w Europie i Stanach Zjednoczonych, zmieniając przy tym kształt od społecznego boomu wyrastającego z korzeni kontrkulturowych (USA), do próby naukowej asymilacji wschodniej myśli filozoficznej w celu wyjaśnienia nowopowstałych odkryć z zakresu psychologii, psychoanalizy, a nawet fizyki kwantowej. Radosław Kossakowski w „Kulturze i Historii" pisze:

[...] prawdziwy boom na buddyzm (nazywany niekiedy zen boom, gdyż to głównie ta odmiana buddyzmu zyskała największą popularność) przypada na lata 50-te i 60-te ubiegłego stulecia. Sporo w tej materii zrobiła kontrkultura. Nasiona pod ów boom zasiały seminaria japońskiego przedstawiciela zen - Daisetz Teitaro Suzukiego. Mieszkał on w Stanach Zjednoczonych od wielu lat, dzięki czemu znał dobrze angielski, co predysponowało go do przedstawienia idei duchowych w czytelny dla Amerykanów sposób. Poza tym, co może najistotniejsze, używał on języka żywego, obdartego z suchego przedstawiania dogmatów, trafiającego do przeciętnego czytelnika. [...] Nic więc dziwnego, że krąg zainteresowania filozofią zen rósł. Suzuki pojawiał się w telewizji, czasopismach „New Yorker” czy „Vogue”. Wykładnia buddyzmu w jego wydaniu docierała też do najznamienitszych przedstawicieli świata sztuki, nauki czy religii (Kossakowski, źródło elektroniczne).

Mając na uwadze dwa zjawiska, po pierwsze: tę szczególną transmisję buddyzmu na Zachód poprzez postać mistrza Zen, D.T. Suzukiego, której także Peter W. Williams poświęca rozdział America's Religions: From Their Origins to the Twenty-first Century (Williams 466-478), po drugie: wpływ buddyzmu na europejskie środowisko filozoficzne połowy XX wieku, za istotną podstawę swoich badań uznaję triadę Beckett - Heidegger - Suzuki, według schematu której buddyzm, a przede wszystkim nauki szkoły Zen, mogłyby dotrzeć do Becketta jako echo wpływu filozofii Martina Heideggera.

O fascynacji Heideggera filozofią Wschodu pisało wielu badaczy, jak chociażby John Steffney w Transmethaphysical Thinking in Heidegger and Zen Buddhism czy Michael Watts w The Philosophy of Heidegger, za każdym razem zgodnie podając nazwisko mistrza D.T. Suzukiego jako tego, którego nauki wpłynęły na filozofa w najbardziej znaczący sposób. Chociaż badacze spierają się co do autentyczności jej pochodzenia, znacząca wydaje się anegdota, przytaczana przez Williama Barretta, jakoby jeden z niemieckich przyjaciół Heideggera, który wszedł do jego pokoju i zobaczył filozofa pochylonego nad pismami Suzukiego, usłyszał: "Jeśli dobrze rozumiem tego człowieka, pisze on to, co ja starałem się wyjaśnić we wszystkich swoich książkach" (Storey 113). Z kolei w 1958 roku, w czasie spotkania Heideggera z innym japońskim mistrzem Zen, Schinichi Hisamatsu, miało dojść do wymiany zdań, które cytuje Cezary Woźniak w artykule „Koniec filozofii" na Zachodzie a buddyzm: 
Hisamatsu: Źródło jest na Zachodzie jakimś bytem, czymś, co ma jakąś postać. W buddyzmie zen źródło jest tym, co bezforemne, nie-bytem. To «nie» nie jest jednakże czystą negacją. Ta nicość jest wolna od wszelkich form, jako całkowicie bezforemna może się ona poruszać zupełnie swobodnie, może się przemieszczać zawsze i wszędzie.

Heidegger: Ta pustka nie jest negatywną nicością. Jeżeli rozumiemy pustkę jako pojęcie od-noszące się do przestrzeni, musimy wówczas powiedzieć, że pustka tej przestrzeni jest właśnie tym, co pomieszczające, tym, co gromadzi wszystkie rzeczy (Woźniak 133).

Zbieżność poglądów osadza się przede wszystkim na założeniu, że „bezpodstawność" bytu (za Woźniakiem) nie musi zmierzać w kierunku nihilizmu, a może stanowić narzędzie zrozumienia istoty tegoż bytu. Co więcej, myśl ontologiczna Heideggera dalece odbiega od filozofii podmiotu i kartezjańskiego subiektywizmu, gdzie rzeczywistość, ze względu na swoją dualistyczną naturę, musi mieć źródło czy to w postaci Boga, czy Pierwszego, Nieruchomego Poruszyciela. W tym sensie brak początku-prawdy i „nicość” stają się pozametafizycznym wyzwoleniem i, podobnie jak w buddyzmie tybetańskim, mogą prowadzić do głębokiego zrozumienia natury świata. Jako przykład podobieństwa myśli filozoficznej Heideggera z buddyzmem Woźniak podaje również termin das Sein, który został wykorzystany przez badacza Herberta V. Guenthera, by przełożyć na język kultury Zachodu termin gzhi (tyb.: 'ziemia'), oznaczający pierwotny stan umysłu, tzw. naturę Buddy, gdzie znika uwarunkwany świat zjawisk, w tym również czas. Z kolei Reinhard May w Heidegger's hidden sources pisze o koncepcjach filozoficznych Heideggera jako tych, które mogłyby stanowić most do zrozumienia filozofii Dalekiego Wschodu, gdyż - mimo że filozof w swoich pracach wspomina nazwiska jedynie dwóch myślicieli tradycji wschodniej (Kuki Shuzo i Laozi) - spotkania z Miki Kiyoshi, Nishitani Keiji czy Tezuka Tomio zaowocowały otwarciem się na nowy, niechrześcijański i niepowiązany ze starożytną grecką szkołą filozoficzną paradygmat kulturowy.

Wracając do triady Beckett - Heidegger - Suzuki, trójosobowy schemat zakłada także podobieństwo poglądów ontologicznych Becketta i Heideggera, którego to wątku poniższy artykuł nie podejmuje ze względu na obszerną literaturę dotyczącą tego tematu ${ }^{6}$.

\section{Buddyjska samsara i kolisty charakter ewolucji Giambattisty Vica}

W tej części badań stawiam hipotezę, że świat bohaterów twórczości Becketta ma te same właściwości co buddyjska samsara. Najważniejsze z nich to: istnienie relatywnych zjawisk, w tym czasu, w uwarunkowanym świecie samsary; cykliczna

6 W tym prace takich badaczy, jak Dermot Moran, Hans H. Rudnick, Michiko Tsushima i Lance St John Butler. 
natura czasu w relatywnym świecie samsary; nieistnienie czasu i relatywnych zjawisk poza uwarunkowaną samsarą ${ }^{7}$. Uważam jednocześnie, że spotkanie Samuela Becketta z Jamesem Joyce'em i zainicjowana tym spotkaniem recepcja historyzmu Vica pomogły Beckettowi ukształtować swoją własną literacką ideę opowiadania historii oraz stały się inspiracją dla stworzenia oryginalnego języka literackiego, który mógłby opisać fenomen czasu ${ }^{8}$. By móc tego dowieść, chciałabym cofnąć się do początku kariery literackiej Becketta i jego rozprawy Dante... Bruno. Vico... Joyce.

Samuel Beckett w wieku dwudziestu jeden lat poznał w Paryżu Jamesa Joyce'a, artyści zaprzyjaźnili się, a Beckett został nieformalnym sekretarzem pisarza podczas pracy nad jego ostatnim dziełem Finnegans Wake. Polscy badacze, wśród nich także Libera, podkreślają echo wpływu Joyce'a na młodego pisarza i jego pierwsze utwory, w tym opowiadania More Pricks Than Kicks i powieść Murphy (Libera 2003: 36), ale wydaje się, że spotkanie z Joyce'em miało kluczowe znaczenie również dla późniejszej twórczości Becketta, przede wszystkim zaś dla jego dojrzałej koncepcji czasu. Bezpośrednim owocem pracy przy Finnegans Wake był pierwszy w karierze Becketta esej, Dante... Bruno. Vico... Joyce, w którym młody pisarz przygląda się dziełu Joyce'a poprzez sylwetki włoskich reformatorów myśli filozoficznej i ich koncepcje czasu oraz historii, dostrzegając jednocześnie w konstrukcji Finnegans Wake wpływ zasady jednorodności przeciwieństw Vica oraz "prawa kołowrotu rzeczy” Bruna (Nowicki 83). Jak pisał Libera w posłowiu do Wierności przegranej:

Myśl Giordana Bruna odciska się w Finnegans Wake pośrednio, poprzez koncepcje Giambattisty Vica, w których została ona zawarta i przetworzona, a które, zdaniem Becketta, stanowią najpoważniejsze źródło inspiracji Joyce'a. Chodzi tu głównie o ideę jednorodności przeciwieństw. Streszcza się ona w zasadzie, że każde minimum odpowiada nie tylko jakiemukolwiek innemu minimum [...], a każde maksimum jakiemukolwiek innemu maksimum, lecz że i każde minimum - jakiemuś maksimum (Libera 1999: 142).

Przemiany wywiedzione z historyzmu Vica mają charakter kolisty. Podobnie jak w idei „kołowrotu” Giordana Bruna, historia u Vica rozumiana jest jako ruch po spirali. Beckett opisuje to w ten sposób:

Historia nie jest ani jakimś tworem amorficznym, powstającym wskutek działań poszczególnych ludzi, ani też czymś, co istniałoby poza nimi, za sprawą jakiejś siły wyższej [...]. Historia nie jest więc wynikiem Losu czy Przypadku - tak czy tak, jednostka pozostawałaby w oderwaniu od swojego wytworu - lecz wynikiem Konieczności, która nie jest Losem, i Wolności, która nie jest Przypadkiem (Beckett 1999: 9).

7 Pojęcie wyjaśniam w dalszej części artykułu.

8 W pracy celowo nie odnoszę się do eseju Becketta Proust z 1931 roku, będącego wielkim traktatem o czasie, biorąc pod uwagę między innymi obszerny artykuł Żanety Nalewajk Kategorie temporalne w wybranych utworach Samuela Becketta. 
Wydaje się, że tak rozumiana za Vikiem cykliczna natura historii, początkowo przypisywana założeniom ideowym Finnegans Wake i przyswojona jako narzędzie interpretacyjne, na stałe przylgnie do Becketta i będzie trwałym elementem dzieł pisarza nie tylko we wczesnej fazie jego twórczości. Vikiańska ewolucja społeczna, zredukowana do losu literackich postaci, nabierze u Becketta slapstickowego tempa. Rytm powtarzających się cyklicznie zdarzeń, zupełnie odwrotnie niż u Joyce'a, zostanie ograniczony do skromnej przestrzeni świata przedstawionego i będzie wybrzmiewać w coraz krótszych formach prozatorskich i dramatycznych. Cykliczność procesów historycznych w pracach Becketta jawić się będzie jako bezwzględna siła ustalająca losy jednostki, na którą owa jednostka nie może mieć wpływu - wszystko dzieje się poza ludzkimi kompetencjami. Przywoływany przez bohaterów Becketta koniec równy jest początkowi, a śmierć i rozkład nieuchronnie prowadzą do narodzin, bowiem „ulica Vica skręca wciąż, by się u kresu zacząć” (Joyce 452). Postaci Becketta nie podlegają żadnemu logicznemu procesowi rodzenia się, życia i umierania, procesowi, w którym zostałoby zachowane prawdopodobieństwo proporcji czasowych. Możemy tu raczej mówić o takim porządku czasowym, w którym postaci, złapane $w$ klincz jednej, określonej sytuacji, przemierzają wciąż tą samą drogę. Postaci te wrzucone są w życie, które jest "głuche i ślepe na wspomnienie Początku oraz wizję Końca” (Klimczak 2006: 184), gdzie ,jedynym faktem pozostaje samoreprodukujące się koło bytu, co symbolizuje koło, które zatacza Hamm poruszający się na wózku inwalidzkim" (Klimczak 2006: 184). Zabieg powtórzenia, objęcia fabularnych zdarzeń zasadą parabolicznej spirali, tworzy wrażenie powrotu do tych samych punktów stycznych w określonych, cyklicznych odstępach czasowych. W niektórych przypadkach dochodzi nawet do rozszczepienia takiej historii na wiele postaci. Przykładem może być tu konstrukcja powieści Molloy (1951), której drugi akapit rozpoczynają wspomnienia głównego bohatera. Tytułowy Molloy wyrusza w podróż, by odnaleźć matkę. Razem z rozwojem fabuły widzimy, jak za Molloyem w tę samą podróż wyrusza, na specjalne zlecenie, prywatny detektyw Jacques Moran. Czytelnik ma wrażenie, że rozwijające się jeden po drugim wątki są na wskroś podobne, a postaci dzieli zaledwie kilkadziesiąt stron opisów zdarzeń z tej samej wędrówki. Również sam narrator włącza się w podróż niczym śledczy historii, który odczuwa przymus jej zapisania. I chociaż dopada go zmęczenie i niechęć, historia, rozpoczęta jakimś irracjonalnym impulsem, pisze się dalej. „Ile kartek, tyle pieniędzy" (Beckett 1983: 5) - mówi narrator Molloya. Jednak i narrator przestaje chcieć mówić. Tak jak tamci, czuje jedynie bezzasadny przymus wykonywania czynności. Mamy więc do czynienia z charakterystycznym chronotopem literackim, w którym cyklicznie płynący czas jest w stanie zagiąć przestrzeń fabularną tak, że niewyraźne rysunki postaci, $\mathrm{w}$ tym narratora powieści, nakładają się na siebie, tworząc kontury jednego bohatera.

Również w krótkiej dramatycznej formie Nie ja wspomniane wrażenie cykliczności, spotęgowane pełną parabol warstwą językową, zbudowane jest poprzez za- 
bieg nałożenia na siebie kilku klisz czasowych. W Nie ja nie widzimy procesu wędrówki czy postępującej w czasie przemiany bohaterów, ale mimo wszystko mamy wrażenie, że w monolitycznej, koherentnej formule gadających ust zawiera się pełne doświadczenie cyklu życia, od narodzin do śmierci. Głos postaci więźnie jeszcze w matczynym łonie, choć jej usta już za chwilę należeć będą do dojrzałej kobiety. W Nie ja czytamy:

USTA: ...na świat... na ten świat... ten świat... takie małe nic... przedwcześnie... w zapadłej - ...co?... dziewczynka?... tak... taka mała dziewczynka... na ten... na ten świat... przedwcześnie... w zapadłej dziurze... zwanej... zwanej... nieważne... rodzice nieznani... żadnego śladu... [...] od razu... tego dnia... więc cienia miłości... nawet takiej... jaką otacza się zwykle... w domu rodzinnym... niemowlę... cienia... cienia miłości... ani takiej... ani innej... żadnej... ani wtedy... ani później... więc typowy przypadek... nic nadzwyczajnego... aż tu na starość... gdzieś pod sześćdziesiątkę... gdy pewnego dnia - ...co?... siedemdziesiątkę?... Matko Boska!... pod siedemdziesiątkę!... (Beckett 1995: 278-279).

Parabolizowanie opowieści sprzyja poczuciu, że postać wciąż się porusza, a ruch ten prowadzi od nowa do tych samych miejsc i sytuacji. Jedyne, co się zmienia, to wciąż ulegająca pogorszeniu kondycja bohaterów, która jest jak tykający zegar, przypominający, że czas jednak płynie. Nieustanne powroty do początku kolejnego, choć lustrzanie podobnego cyklu zdarzeń męczą bohaterów i są źródłem potwornej frustracji. Spirala, po której poruszają się z gasnącą siłą bohaterowie Becketta, nie tylko przywołuje skojarzenie z ideą jednorodności przeciwieństw Vica, ale również z buddyjską samsarą ${ }^{9}$, cyklem narodzin - śmierci - ponownych narodzin.

Samsara przedstawiana jest często za pomocą symbolu bhavachakry (inaczej „koło życia”) (Grela 72). Według buddyzmu jej cechą szczególną jest to, że istnieje tylko w relatywnym świecie zjawisk (Przybysławski 578). Choć samsara jest źródłem ogromnego cierpienia, bez odpowiedniego poglądu buddyjskiego człowiek nie jest w stanie przerwać samsarycznej wędrówki, koła narodzin i śmierci, gdyż jej podstawą jest właśnie niewiedza, to ona jest pierwszym i uruchamia jedenaście kolejnych ogniw współzależnego powstawania (Gyatso 25). Uwarunkowana samsara nie ma początku, nie kieruje nią żaden Stwórca, jednak nic w niej nie istnieje bez przyczyny i samodzielnie. Mechanizm samsary funkcjonuje dzięki karmanowi, często nazywanemu też karmą („uczynkowi”, ,'działaniu” lub „sumie uczynków”). Pragnienie działania wywołane błędną wizją rzeczywistości obciąża człowieka następną for-

9 „Sansara [sanskr. saṁsāra 'przepływanie'] w myśli indyjskiej oznacza koncepcję reinkarnacji, łańcuch wcieleń, którego przyczyną jest karman, a także przechodzenie przez różne stany (ciało ludzkie, zwierzęce lub roślinne), zależnie od jakości uczynków w poprzednim życiu, całkowite oddzielenie duszy od materii następuje po wyzwoleniu się z sansary i osiągnięciu miejsca wiecznego pokoju" (Sansara, źródło elektroniczne). 
macją karmy i utrzymuje w kole wcieleń. Tylko zrozumienie nietrwałości tego, co uważamy za rzeczywiste, oraz wygaszenie długo budowanego przywiązania do relatywnych światów samsary pozwala uwolnić się i osiągnąć stan oświecenia.

Świat postaci Becketta ma cechy samsary, zredukowanej do jej najdotkliwszego oblicza, mające swe odbicie w strukturze tekstu dramatycznego, na który składają się niekończące się powtórzenia, parabole i inne zabiegi literackie, pozwalające czytelnikowi odczuć dotkliwe działanie czasu.

Według nauk buddyjskich czas istnieje tylko w uwarunkowanej samsarze, kiedy zaś znikają wszystkie relatywne warunki, czas również znika. W Końcówce Becketta to przeczucie świata nieuwarunkowanego, świata bez czasu, pojawia się w tle, w widoku przez okno, w oddaleniu od samsarycznego kołowrotu zdarzeń, które odbywają się w czterech ścianach dramatu.

Końców ka zaczyna się od słów Clova: „Skończone, skończyło się, kończy się już, to chyba się już kończy" (Beckett 1995: 114). Po krótkiej pauzie ze sceny pada zdanie: "Ziarnko do ziarnka, po jednym, aż nagle, któregoś dnia, jest stos, mały stos, niemożliwy stos" (Beckett 1995: 114).

Tak samo jak stos nigdy się nie kończy, w uwarunkowanej, dualistycznej samsarze niemożliwy jest koniec cierpienia bohaterów Końcówki. Dzieje się tak ze względu na obecność ego, ciągłą potrzebę działania i nawykowe lgnięcie do relatywnych zjawisk. Jest jednak przeczucie czegoś poza nieuchronnością cierpienia. Clov widzi chłopca: „Wygląda jakby siedział na ziemi, oparty o coś plecami” (Beckett 1995:167). Clov opuszcza lunetę i odwraca się w stronę Hamma: „Na swój pępek” (Beckett 1995: 167). Niezależnie od tego, kim jest obserwowany przez Clova chłopiec, Mojżeszem czy Buddą, ta wyraźna przepaść między „nieruchomością” czasu poza granicą relatywnego świata zdarzeń, czyli „za ścianami” Końcówki, a jego niszczącą mocą, przywołuje porównanie z kołowrotem samsary i możliwym samadhi (Kapleau 93), czyli stanem wolnym od lgnięcia do zjawisk, stanem, w którym znika relatywne postrzeganie zjawisk, znika też czas. Samadhi, nazywane często „medytacyjnym pochłonięciem" (Głębsze poziomy medytacji mahamudry, źródło elektroniczne), nigdy nie będzie dane Hammowi, jeśli krótka iluminacja związana z zauważeniem rzeczywistości za szkłem lunety nie zamieni się w długą kontemplację. Bohaterowie sztuk i powieści Becketta boją się podjąć ryzyko wyrwania z samsarycznej rzeczywistości. Czasem, jak Hamm, spoglądają za okno. Gruba ściana dzieli te dwa światy w jednym uwikłani w czas Clov i Hamm nieustannie przelewają "gnuśny, blady i jednobarwny płyn przyszłości do naczynia z płynem przeszłości, zbełtanym i zabarwionym płynem minionych godzin" (Beckett 1999: 34), w drugiej mały chłopiec, którego „umysł jest jak spokojna, głęboka, krystalicznie czysta woda i w sposób całkowity i doskonały odbija «księżyc prawdy»" (Kapleau 44), patrzy spokojnie na swój pępek. Odbiorca ma wrażenie, że wraz z bohaterami utknął w pułapce działania. Klimczak zauważa, że antidotum może stanowić taoistyczna zasada wu wei (w chińskim: 'niedziałanie, niezrobienie, niedążenie'). Wyjaśnia: „Chodzi o to, aby- 
śmy przestali dążyć do rzeczy nierzeczywistych, które sprawiają, że ślepniemy i nie widzimy naszej prawdziwej Jaźni" (Klimczak 2004: 346). Według nauk taoistycznych wu wei inicjuje stan, w którym człowiek przestaje lgnąć do zjawisk, a tym samym przestaje być częścią koła samsary.

\section{Wedyjska maya i i chęć powrotu do matczynego łona}

Klimczak, by opisać relatywny, uwarunkowany świat literacki Becketta, używa wywiedzionego z tradycji wedyjskiej terminu maya. Pojęcia mayi i samsary są ze sobą ściśle powiązane. Badacz pisze: „pobyt w materialnym świecie bez rzeczywistego przebywania w nim oznacza podporządkowanie się iluzorycznej energii, która w sanskrycie nazywa się maya" (Klimczak 2004: 341). Wedyjska maya znaczy tyle co iluzja, namacalna i mentalna rzeczywistość, codziennie absorbująca świadomość żywych istot, zakrywająca przed nimi prawdę na temat samych siebie. Skojarzenie $\mathrm{z}$ buddyjskim terminem maya wydaje się o tyle trafione, o ile etymologicznych związków wedyjskiej mayi można szukać w imieniu matki Buddy Sakjamuniego Maya. I tak, strach przed uwolnienieniem się od mayi, tłumaczonej jako przywiązanie do własnego ciała i iluzorycznego świata zjawisk, może w pośredni sposób, wychodząc poza założenia Klimczaka, reprezentować też strach przed narodzinami i regresywną chęć powrotu do matczynego łona.

Niechęć do narodzin odczuwa tytułowy bohater Molloya. Symbolika Molloya przywodzi na myśl nie tylko, jak sugeruje Ruby Cohn w Back to Beckett (Cohn 84), archetypiczny obraz zachodniego tułacza - męczennika podobnego do Chrystusa czy Odyseusza. Oczywiście, za autorem, Molloy jest reprezentantem tradycyjnej myśli zachodniej i, jak widzi go Cohn, wystawia ją na ciężką próbę. Jest komiczny, nieporadny, zatopiony po kolana w błocie, co rusz boryka się z kolejnym defektem ciała. Jednak Molloy to również pastisz na starożytne kanony piękna i siły oraz chrześcijańską potrzebę odgadywania sensu w cierpieniu. Bowiem Molloy z Odyseusza i Chrystusa wziął to, co przestało przystawać do świata mu współczesnego. Wysiłki Molloya zdają się bezsensowne, czasem nawet ordynarnie głupie. Po co właściwie Molloy wyrusza w podróż? Skąd wyrusza i dokąd zmierza? Odpowiedzi na te pytania prowadzić mogą o wiele dalej, poza systemy filozoficzno-religijne Zachodu. Począwszy od matczynego łóżka, od którego rozpoczyna się opowieść, aż po cel bohatera, jakim jest odnalezienie własnej, być może zmarłej matki, wędrówka Molloya zatacza bezsensowne koło, w które wpadają następnie detektyw Moran i narrator. Wrzucone mechanicznie w bieg podróży postaci nie wiedzą, skąd przyszły i dokąd zmierzają. Chcą poznać prawdę o sobie. Są jak Molloy, który, zobowiązany niewytłumaczalnym imperatywem, podejmuje się bolesnej wędrówki, ale, mimo wysiłków, nie jest w stanie dogonić matki. Ostatnie zdania pierwszej części Molloya brzmią: „Zdawało mi się, że kolejno to pada, to świeci słońce. Prawdziwie 
wiosenny czas. Miałem ochotę wrócić do lasu. Ach, to nie była prawdziwa ochota. Molloy mógł zostać tam, gdzie był" (Beckett 1983: 97).

Molloy nie może przestać iść. Proces uwalniania się od świata relatywnych zjawisk jest równie trudny jak uwalnianie się od matczynego łona, wobec którego lojalność dziecka jest niepomiernie wielka. Przywiązanie bohatera do matki obrazuje po pierwsze: silny nawyk człowieka do kurczowego trzymania się warunków najbliższych jego naturze, które stanowią tak naprawdę iluzję trwałości i bezpieczeństwa, po drugie: lęk przed narodzinami, czyli przed światem pełnym cierpienia. Lęk ten w naukach buddyjskich jest często podejmowanym tematem i zbieżność tę zauważa również Klimczak: „U Becketta - tak jak w religii buddyjskiej - niechęć do narodzin jest czymś oczywistym w świetle jednego podstawowego przesłania, głoszącego, że narodziny, choroba, starość, Śmierć - są cierpieniem" (Klimczak 2004: 349).

Lęk przed narodzinami odnosi się do tej fazy uzyskiwania świadomości przez dziecko, kiedy fizycznie narodzone, oddziela się od rodzica i rodzi ponownie - jako odrębne istnienie. Cierpienie związane $\mathrm{z}$ aktem narodzin powoduje wstręt i poczucie, że wszystko, co nastąpi po nim, będzie powodowało ból. Ogarniające bohaterów Becketta uczucie wyparcia z matczynego łona analizowało wielu badaczy, jak chociażby Rubin Rabinovitz w artykule Beckett and psychology w "Journal of Beckett Studies" (Rabinovitz 65), koncentrując się głównie na jej psychoanalitycznym aspekcie. Jednak dopiero Klimczak zauważa podobieństwo założeń Becketta z filozofią buddyjską.

Podobne asocjacje z matczynym łonem budzi również topos kopca, w którym znajduje się ciało Winnie, bohaterki Szczęśliwych dni, choć tutaj Klimczak proponuje raczej skojarzenie z indyjską stupą czy buddyjską pagodą. Pisze: „podobny archetyp odnajdujemy $\mathrm{w}$ grobach starożytnej cywilizacji mykeńskiej i greckiej, $\mathrm{w}$ egipskich piramidach, grobowcach okresu rzymskiego, a także w buddyjskich stupach i pagodach" (Klimczak 2004: 357). Badacz wskazuje na wagę umierania w kulturze Wschodu, gdzie świadome popadanie w śmierć jest raczej tryumfem niż tragedią. Odwołuje się do Tybetańskiej Księgi Umarłych, według której ostatnie myśli umierającego mają wpływ na naturę jego pośmiertnych doświadczeń i kolejną inkarnację, jeśli nie uda się wejście w stan oświecenia. Takie skojarzenie autora prowokuje dyskusję na temat etymologii imienia bohaterki Szczęśliwych dni. Winnie od angielskiego win ('zwycięstwo, wygrana, zdobywać') wskazuje na heroiczne cechy postaci, co w połączeniu z imieniem drugiego bohatera dramatu, Willie (ang. will, 'wola'), w kontekście ustaleń Klimczaka wyraża sens całego dramatu: "My last will is going to win" (Klimczak 2004: 355). Winnie rzeczywiście jako jedna z niewielu z postaci Becketta ma w sobie ducha zwycięzcy. Specyfika jej języka, w którym szczególną uwagę przykuwa wywiedzione z dziecięcych nawyków mówienia frazowanie, jaskrawo kontrastuje z obrazem kopca piachu, w którym tkwi jej ciało. Oddzielające kolejne zapadania się Winnie w ziemię dźwięki dzwonka nie oznaczają upływu czasu, bo Winnie istnieje poza czasem scenicznym, sama jest 
swoim Istnieniem-Czasem (Kapleau 274). Zapadanie się w kopcu może symbolizować decyzję o zerwaniu z relatywnym światem samsary i nadzieję na oświecenie. W tym kontekście interpretacja Klimczaka, rozszyfrowująca dźwięki dzwonka w Szczęśliwych dniach jako dźwięki ghanty ${ }^{10}$, rodzi kolejne skojarzenia. Klimczak nie dodaje najważniejszego. Ghanty (w języku tybetańskim dril bu) używa się podczas praktyki czöd (Magnuszewska, źródło elektroniczne), praktyki „odcięcia ja” związanej z tantrami jogi najwyższej, którą wykonuje się tradycyjnie na cmentarzach lub w innych miejscach pochówków, często jako element obrządku pogrzebowego, by ostatecznie pokonać przywiązanie do ego. Kopiec Winnie czytany jako część rytuału czöd zmienia perspektywę interpretacyjną Szczęśliwych dni. Winnie nie jest już bowiem niewolnikiem Tanatosa (w psychoanalizie: popęd śmierci). Staje się raczej symbolem wyzwolenia od „,ja", figurą walki Becketta z dualizmem kartezjańskim. W tym sensie postać Winnie obrazuje nienihilistyczną syntezę „bezpodstawności”, o której Heidegger rozmawiał z mistrzem Zen w 1958 roku, a uczeń Heideggera, Keji Nishitani, pisał, że nie może być zrozumiana bez odwagi wyjścia poza perspektywę zachodnią (Woźniak 131). Winnie bowiem, unieruchomiona w kopcu piachu, poddaje się biegowi zdarzeń.

\section{Wadzenie się z Zachodem}

Marek Kędzierski w wywiadzie przeprowadzonym przez Krzysztofa Myszkowskiego na łamach „Kwartalnika Artystycznego” zauważa: „Beckett wadził się z Bogiem obecnym w kulturze, Bogiem takim, jakim go przedstawia kultura, głównie kultura Zachodu" (Kędzierski 197). To wadzenie się, tak oczywiste w obliczu wojennych doświadczeń pokolenia Becketta, przyniosło niezliczone interpretacje i prace beckettologiczne, głównie w duchu psychoanalizy i pojęć teologicznych wywiedzionych z chrześcijaństwa oraz judaizmu. Jednak w światowej krytyce literackiej nie brakuje pozycji w całości lub częściowo poświęconych interpretacji twórczości Becketta z perspektywy dalekowschodnich nurtów filozoficznych. Opierają się one głównie na założeniu, że twórczość ta może nieść nowe dla kultury zachodnioeuropejskiej lub amerykańskiej wartości dzięki wpleceniu w tkankę tekstu pewnych dających się wyjaśnić za sprawą Schopenhauerowskiej terminologii zabiegów literackich. Korzystające z nomenklatury Schopenhauera przeniesienie Wschodu na artystyczną reprezentację myśli filozoficznej Becketta broni się niepodważalnym zapleczem faktograficznym, ma jednak swoje słabe strony, jak chociażby wybiórczość. Przeniesienie to wynika najpewniej z chęci zachowania rzetelności i ze swego

10 „Ghanta: (język tybetański: dril bu, sanstryt: ghanta) w buddyzmie tybetańskim rytualny dzwonek, podczas obrzędów czöd trzymany w lewej (,kobiecej”) ręce. Symbolizuje doskonałą mądrość (skt.: pradźńa)" (Ghanta, źródło elektroniczne). 
rodzaju asekuracyjnego nastawienia badawczego. Tymczasem, skłaniając się ku refleksji z początku artykułu, w mojej ocenie nie jest najważniejsze znalezienie dowodu na istnienie powiązania Becketta z myślą Wschodu czy filozofią Martina Heideggera, kluczowe natomiast, z punktu widzenia trendów nowej humanistyki, staje się szukanie nieopisanych dotąd związków literatury ze światowymi nurtami filozofii. Mam nadzieję, że nawet jeśli perspektywa badawcza, na której oparta jest pierwsza część artykułu, i która zakłada, że Beckett, w części za sprawą Martina Heideggera, w części za sprawą ogólnych trendów kulturowych w Europie lat sześćdziesiątych, spotkał się z buddyzmem, wciąż budzi wątpliwości, to czytanie twórczości Becketta poprzez buddyzm, jak uczynił to chociażby Klimczak, nie tylko dowodzi uniwersalnego charakteru dzieł pisarza, ale czyni z nich przydatne narzędzie w kulturoznawczym dialogu Wschód - Zachód.

\section{BIBLIOGRAFIA}

Bachtin, Michaił. Problemy literatury i estetyki. Przeł. Wincenty Grajewski. Warszawa: Czytelnik, 1982.

Beckett, Samuel. Dramaty. Przekład, wprowadzenie i opracowanie Antoni Libera. Wrocław: Zakład Narodowy im. Ossolińskich, 1995.

Beckett, Samuel. Malone umiera. Przeł. Marek Kędzierski. Kraków: Oficyna Literacka, 1997.

Beckett, Samuel. Molloy. Przeł. Maria Leśniewska. Kraków - Wrocław: Wydawnictwo Literackie, 1983. Beckett, Samuel. „Nienazywalne”. Przeł. Marek Kędzierski. Kwartalnik Artystyczny 1 (2007). S. 7-14.

Beckett, Samuel. Watt. Przeł. Marek Kędzierski. Bydgoszcz: Pomorze, 1993.

Beckett, Samuel. Wierność przegranej. Przekład, wybór i posłowie Antoni Libera, Marcin Nowoszewski. Kraków: Wydawnictwo Znak, 1999.

Błoński Jan, Kędzierski Marek. Samuel Beckett. Warszawa: Czytelnik, 1982.

Celli, Nicoletta. Buddyzm. Warszawa: Wydawnictwo Arkady, 2010.

Chien, Meng-Ling (簡孟凌). Samuel Beckett's Waiting for Godot and Endgame: Language, Suffering and Nothingness Interpreted in the Light of Buddhist and Daoist Thought. 國立成功大學. 2005.

Coe, Richard N. Samuel Beckett. Nowy Jork: Grove Press, 1970.

Cohn, Ruby. Back to Beckett. Princeton: Princeton University Press, 1973.

Cronin, Anthony. "Samuel Beckett. Od Molloy'a do Nienazywalnego". Przeł. Barbara Bernhardt, Marek Kędzierski. Kwartalnik Artystyczny 4 (1999). S. 49-66.

Dalai Lama. "Głębsze poziomy medytacji mahamudry”. Web. 17.10.2018. <https://studybuddhism. $\mathrm{com} / \mathrm{pl}$ /studia-zaawansowane/wadzrajana/mahamudra-nauki-zaawansowane/praktyczne-zastosowanie-mahamudry/glebsze-poziomy-medytacji-mahamudry>

Esslin, Martin. „Późne sztuki Samuela Becketta”. Dialog 12 (1976). S. 129-133.

Foster, Paul. Beckett and Zen: A Study of Dilemma in the Novels of Samuel Beckett. Massachusetts: Wisdom Publications, 1989.

Fromm Erich, Suzuki Daisetz Teitaro, de Martino Richard. Buddyzm zen i psychoanaliza. Przeł. Marek Macko. Poznań: Dom Wydawniczy Rebis, 2011. 
Gąsiorowski, Jacek. „Kto mówi nie ja”. Dialog 7 (1973). S. 92-94.

Gendyn, Lama Rinpocze. Mahamudra. Przeł. Aleksandra Migacz. Kraków: Wydawnictwo A, 2012.

Grela, Joanna. „Buddyjskie prawo karmana w tradycji tybetańskiej”. Studia Religiologica 37 (2014). S. 71-83.

Gyatso, Lobsang. The Four Noble Truths. Ithaca: Snow Lion Publications, 1994.

Hongzhi Zhengjue. Cicha iluminacja. Przeł. Dan Leighton, Bon Gak. Warszawa: Wydawnictwo Miska Ryżu, 2009.

Hsiao, Shih-ping (蕭世萍). Samuel Beckett's Waiting for Godot: Suffering and Emptiness--An Interpretation in the Light of Buddhism 塞謬爾貝克特的《等待果陀》: 苦與空 - 以佛教的觀點解讀. 國立成功大學, 1999.

Kalinowski, Daniel. „Konflikt i koegzystencja. Spotkanie buddyzmu i kultury Zachodu”. 2007. Web. 15.09.2018. <http://www.buddyzm.edu.pl/cybersangha/page.php?id=873>

Kapleau, Philip. Trzy Filary Zen. Warszawa: Wydawnictwo Pusty Obłok, 1990.

Kaur, Pavneet. "Samuel Beckett's 'The Way' and Stirrings Still: Analysing the Self from 'Schopenhauerian Buddhist' Perspective". Sanglap 4.1 (2017). S. 69-79.

Kędzierski, Marek. „Pułapka Becketta”. Kwartalnik Artystyczny 3/4 (2006). S. 197-209.

Klimczak, Dariusz Piotr. „Medytacja nad Pustką. Konteksty buddyjskie w Końcówce i Szczęśliwych dniach Samuela Becketta". Przestrzenie Teorii 3/4 (2004). S. 337-367.

Klimczak, Dariusz Piotr. Śmiertelnicy. Teatr Absurdu Samuela Becketta w przestrzeni Misterium Mortis. Kraków-Warszawa: Instytut Wydawniczy „Maximum”, 2006.

Kosior, Krzysztof. “Krótka historia buddyzmu w Europie”. Annales Universitatis Mariae Curiae-Skłodowska. Philosophia-Sociologia 27 (2002). S. 167-182.

Kossakowski, Radek. „Dharma na Zachodzie -historia przenikania się kultur”. Kultura i Historia. 2012. Web. 15.09.2018. <https://www.kulturaihistoria.umcs.lublin.pl/archives/3443>

Kwong, Jakusho. Bez początku, bez końca - intymne serce zen. Warszawa: Wydawnictwo Świat Książki, 2005.

Lati Rinpocze, Hopkins Jeffrey. Śmierć, stan pośredni i odrodzenie w buddyzmie tybetańskim. Przeł. Wiesław Kurpiewski. Kraków: Wydawnictwo A, 1999.

Libera, Antoni. „Być sobą - co to znaczy? Studium Ostatniej taśmy Samuela Becketta”. Kwartalnik Artystyczny 4 (2003). S. 36-37.

Libera, Antoni. „Człowiek jest jak dziecko, które zmyśla samo siebie”. 2008. Web. 16.08.2018. <http:// www.antoni-libera.pl/node/120>

Libera, Antoni. „Posłowie”. Beckett, Samuel. Wierność przegranej. Przekład, wybór i posłowie Antoni Libera, Marcin Nowoszewski. Kraków: Wydawnictwo Znak, 1999.

Lin, Lidan. “Samuel Beckett's Encounter with the East". English Studies 91 (2010). S. 623-642.

Magnuszewska, Marzena. „Buddyzm tybetański (8) - Niezwykłe praktyki”. Indie szeroko pojęte. 2016. Web. 16.09.2018. <http://www.indieszerokopojete.pl/buddyzm-tybetanski-8-niezwykle-praktyki/>

May, Reinhard. Heidegger's hidden sources. East Asian Influences on His Work. Londyn-Nowy York: Routledge, 2005.

Merton, Thomas. Zen i ptaki żądzy. Kraków: Wydawnictwo Znak, 1995.

Momro, Jakub. Literatura Świadomości. Samuel Beckett - Podmiot - Negatywność. Kraków: Horyzonty Nowoczesności, 2010. 
Nalewajk, Żaneta. „Kategorie temporalne w wybranych utworach Samuela Becketta”. Tekstualia 1 (2010). S. 61-72.

Norbu, Namkhai Chögyal. Yantra Yoga: The Tibetan Yoga of Movement. New York: Snow Lion Publications, 2008.

Nowicki, Andrzej. Giordano Bruno. Warszawa: Wiedza Powszechna, 1979.

Przybysławski, Artur. „Pojęcie świadomości uwarunkowanej w filozofii buddyjskiej”. Przegląd Filozoficzny. Nowa Seria 21 (3) (2012). S. 577-584. Web. 16.09.2018. <http://cejsh.icm.edu.pl/cejsh/element/bwmeta1.element.doi-10_2478_v10271-012-0100-8/c/przybyslawski_pojecie_swiadomosci_ uwarunkowanej_w_filozofii_tybetanskiej.pdf>

Rabinovitz, Rubin. "Beckett and psychology". Journal of Beckett Studies 11/12 (1989). S. 65.

Rosen, Steven J. Samuel Beckett and the pessimistic tradition. New Jersey: Rutgers University Press, 1976.

Schlingloff, Dieter. Buddyzm. Monastyczna i świecka droga zbawienia. Oprac. M. Mejor. Przeł. Leon Żylicz. Warszawa: Wydawnictwo Akademickie Dialog, 2004.

Schumacher Stephan, Woerner Gert. Encyklopedia mądrości Wschodu: buddyzm, hinduizm, taoizm, zen. Przeł. Mieczysław Jerzy Künstler. Warszawa: Warszawski Dom Wydawniczy, 1997.

Sieradzan, Jacek. „Koncepcja umysłu w buddyzmie”. Idea - Studia nad struktura i rozwojem pojęć filozoficznych 19 (2007). S. 13-32. Web. 16.09.2018. <https:// repozytorium.uwb.edu.pl/jspui/bitstream/11320/1471/1/Idea_2007_19_Sieradzan.pdf>

Steffney, John. "Transmethaphysical Thinking in Heidegger and Zen Buddhism". Philosophy East and West 3 (1977). S. 323-335.

Storey, David. "Zen i Heidegger's Way". Journal of East-West Thought, 4 (2012). S. 113-137. Web. 18.10.2018. <https://www.cpp.edu/ jet/Documents/JET/Jet5/Storey113-137.pdf>

Suzuki, Daisetz Teitaro. Wprowadzenie do Buddyzmu Zen, Kraków: vis-a-vis / Etiuda, 2009.

Tatarkiewicz, Władysław. Historia filozofii. Warszawa: PWN, 1970.

Veisland, Jørgen. Drama and repetition. Olecko: Wydawnictwo Wszechnicy Mazurskiej, 2009.

Vico, Giambattista. Nauka nowa. Oprac. S. Krzemień-Ojak. Przeł. Jan Jakubowicz. Warszawa: Biblioteka Klasyków Filozofii PWN, 1966.

Watts, Michael. The Philosophy of Heidegger. New York: Acumen Publishing, 2014.

Williams, Peter. America's Religions: From Their Origins to the Twenty-first Century. Urbana, Chicago, Springfield: University of Illinois Press, 2015.

Wilowski, Włodzimierz. „Chrześcijaństwo a buddyzm zen. Ewangelizacja czy dialog?”. Humaniora 4 (2014). Web. 17.10.2018. <http://humaniora.amu.edu.pl/sites/default/files/humaniora/Humaniora\%20nr\%208/Hum_4_14_Wilowski.pdf>

Woźniak, Cezary. „«Koniec filozofii» na Zachodzie a buddyzm”. Zeszyty Naukowe Uniwersytetu Jagiellońskiego. Studia Religiologica 37 (2004). S. 125-139. Web. 17.10.2018. <http:/ / www.ejournals.eu/sj/ index.php/SR/article/viewFile/2539/2547>

Złakowska, Kamila. „Emanacje czasu - Proust i Beckett”. Twórczość 3 (2001). S. 79-94.

Znaniecki, Florian. „Narzędzie rozumienia: wspótczynnik humanistyczny”. Antropologia kultury. Zagadnienia i wybór tekstów. Red. A. Mencwel. Warszawa: Wydawnictwo Uniwersytetu Warszawskiego, 2001. S. 470-473. 